\title{
Possibilities of Advancing Police Reform in Guatemala through Community-oriented Policing
}

\author{
Arturo Matute \\ Faculty of Social Sciences, University of the Valley of Guatemala, Guatemala City, Guatemala \\ Corresponding author: amatute@uvg.edu.gt; Tel.: +502 42709521
}

Submitted: 4 May 2020 | In revised form: 18 January 2021 | Accepted: 25 January 2021 |

Published: 22 March 2021

\begin{abstract}
The paper describes the process of security sector reform in Guatemala with reference to the efforts to implement community-based policing practices. The results point to the difficulties of shakingoff public understandings of security honed during the armed conflict and underscore the efforts of a still young police institution to position itself in a democratic context. The study posits that communityoriented policing strategies open opportunities to forward police reform in the high-violence, low-trust, weak-institutions, and post-conflict context of Guatemala. The argument is supported by field data gathered in indigenous territories in the Western Highlands, where traditional forms of social organization persist, and in metropolitan Villa Canales municipality, an urban, high-violence site of research.
\end{abstract}

Keywords: Community-oriented policing; crime prevention; democratization; Guatemala; participation; police reform; post-conflict context

\section{Introduction}

Police reform has been sought in Latin America since authoritarian regimes declined in the late $20^{\text {th }}$ century. In Guatemala, the peace accords of 1996 ended one of the longest and most brutal civil wars in the continent in which more than 200,000 people were killed, 93 per cent at the hands of the military which carried out a scorched-earth policy that effectively destroyed the guerrillas' social support networks in what amounted to "acts of genocide" against indigenous groups [1]. During the war the military expanded its power over all of society controlling the judicial system, promoting political parties to press for its interests and establishing a stratum of former officers with multiple business concerns [2]. In this context the National Police was an instrument to suppress opposition which actively participated in capturing, secluding, torturing and frequently eliminating actual or alleged members of the resistance.

Police reform was effectively launched in Guatemala with the creation of the National Civilian Police (PNC, Spanish acronym) by the peace accords to replace the conflictera security bodies. The accords established that the PNC would act in full respect of human rights, under the leadership of civilian authorities, and in collaboration with representatives of the communities it serves. This was an essential part of the effort to transform Guatemalan security policy from counterinsurgent opprobrium to a humansecurity paradigm where the rights of the citizens are the center of concern of state action.

Regrettably, more than two decades later, those highminded objectives have not been achieved. With no democratic antecedents, under control of venal political administrators, with weak administrative structures, a perennial shortage of funds and always vulnerable to 
pressures to remilitarize, the PNC has struggled to develop into an effective security institution during its 23 years of existence [3].

A state of permanent crisis demands immediate attention from the police to the manifold aspects of violence and crime in Guatemala. Economic stagnation and social neglect from politicians have favored conditions for interpersonal violence in the form of common crime on the streets, or domestic abuse fueled by male chauvinism and alcohol consumption. Street-gangs manage extortion schemes that affect enterprises of all sizes and which are many times enforced through lethal violence. Transnational criminal organizations operate in Guatemalan territory in cahoots with local felons running drugs, weapons and human trafficking. Demands to repress community mobilizations against extractive industries in cases of badly managed land, water, and energy conflicts sporadically come about as well.

Despite the obstacles that high levels of internal and transnational crime, under-resourced and weak institutions, and the absence of a democratic heritage pose, some favorable elements for police reform are also in place. An important reduction in violence levels has been achieved since 2010, National Civilian Police officers trained during the conflict-era are ceding leadership positions to a newer generation, and, as fieldwork for this study shows, there are elements on which to build trust between communities and police people deployed in the territories.

Adaptations of community-oriented policing (COP) strategies that originated in developed countries have been a part of every major effort at police reform in Latin America [4]. Guatemala has not been the exception. Dabs at enacting community-oriented strategies that began at the turn of the century have become more stable since the establishment of the Integral Community Security Police Model (MOPSIC, its Spanish acronym) within the PNC in 2014. As will be described below, the MOPSIC provides tools and establishes guidelines for the Guatemalan Police to increase its capacity to relate with communities and cooperate in the production of secure environments.

The continuity of such strategies is conditioned by the fact that police reform is more a political than a technocratic issue. In this light, the present article does not intend to make the point that the path towards reform is sustainable and that community-based strategies are warranted in Guatemala as the commitment of higher-level authorities has only been sporadic for this to happen. The development of COP in the Guatemalan PNC has hinged on the work of rising professionals within the institution combined with international donor support. The objective of this article, rather, is to provide evidence that despite the difficulties it faces, community-oriented policing strategies open some opportunities to forward police reform in the high-violence, low-trust, weak-institutions, and post-conflict context of Guatemala.

The MOPSIC provides tools, develops knowledge, and enhances a different understanding among police members of what their role must be: to protect and serve the population. First and foremost, Guatemala needs its police force to cease being an aggressor. Fostering cooperative structures in which "... community [...] takes a lead in establishing local norms, working with the police, and resolving internal tensions in ways that promote overall security while leaving basic law enforcement in the hands of the police" ([5], pp. 11-12) is a contribution towards these limited goals. Such institutional evolution contributes to abrade the authoritarian-militaristic approach to public security that the Guatemalan state has been based on since its inception.

After the signing of Peace Accords, specialists in the use of violence that were part of the repressive apparatus of the military governments transformed into "violent entrepreneurs" that have established relations with the new governing elites in northern Central America and have frequently taken up the highest security posts in these countries [6]. The continuation of this "militarized culture [,] inhibits the police's ability to engage with the community as public servants rather than as agents of an anxious state" ([7], p. 174). Despite these delays in the democratization of security and the pressure towards remilitarization they entail, the Guatemalan PNC has been able to avoid complete over-take. Although besieged, the PNC has kept its identity as a civilian institution, effort in which the take up of COP strategies has been an important component. COP is a contraposition, a counterexample to militarization. It contributes to civilianize security, increase the possibilities for citizen oversight, and eventually for the development of stronger accountability mechanisms. COP strategies are well positioned to respond to crime concerns based in the territories inhabited by the affected population, including domestic, common and even street-gang crime. They have been instrumental in bringing about a significant decrease in homicidal violence and several other indicators of crime.

This reasoning arises from the study of the implementation of COP strategies in two highly differentiated localities in Guatemala taking into account the experience, attitudes and opinions of communities and police people deployed in the territories. The article critically examines the assessment that security sector authorities, international donors and experts of COP implementation make regarding its significance for wider police reform as well. The research reveals that, even if trust is low towards the police, the community is not fully alienated from it in Guatemala. Elements of empathy towards each other are in place on which structures of social cooperation can be built. Sustaining COP strategies contributes to develop a human-security approach.

A closer consideration of the circumstances in which the process has and continues to take place sheds light on unaccounted-for factors that can invigorate the implementation of COP and of wider police reform in Guatemala. The article begins with an overview of the development of the institution within recent history followed by a presentation of the material and methods used in the research. Then, it presents the results of research carried out in two selected municipalities using Frühling's framework to assess COP implementation [4]. The piece ends with an analytical discussion of the results and provides some conclusions and recommendations. 


\section{Vignette: Evolution of homicidal violence in Guatemala and its region}

A short phase of decrease in the homicide rate that went from 38.2 per every 100,000 inhabitants in 1997 to 24.2 in 1999 was associated to the establishment of the National Civilian Police. It was followed by an increasingly chaotic period in the first decade of the 21 st century marked by lawlessness instigated by the heightened presence of narcotics trafficking organizations in the Guatemalan territory, the stagnation of social indicators of well-being, increasing income inequality, growth in the operation of street-gangs mainly in marginal urban neighborhoods accompanied by inept and inefficacious responses from the security apparatus. From 1999 until 2009 homicide rates grew approximately $7 \%$ each year as can be seen in the graph below. The absolute numbers went from 2,655 homicides in 1999 to 6,498 in 2009 . Since then, and correlated with the implementation of strengthened interinstitutional collaboration in crime investigation strategies, the homicide rate has decreased steadily (Figure 1).

When compared to the most violent of its neighbors, El Salvador and Honduras, with which Guatemala constitutes the so-called "Northern Triangle" of Central America, what's most notable is the constant descent in homicide rate levels that Guatemala has sustained since 2009 , the volatility of El Salvador, and the non-coincidence with Honduras' variations. It is also notable that Mexico can be considered among the most violent countries in the region since 2017 . This shows that the evolution of homicidal violence is mainly determined by national dynamics, not to regional tendencies (Figure 2 ).

Should Guatemala's homicide reduction trend continue, it will soon join the group of its low-violence neighbors that sustain homicide levels well below the Latin American average of 23 per 100,000 inhabitants (Figure 3).

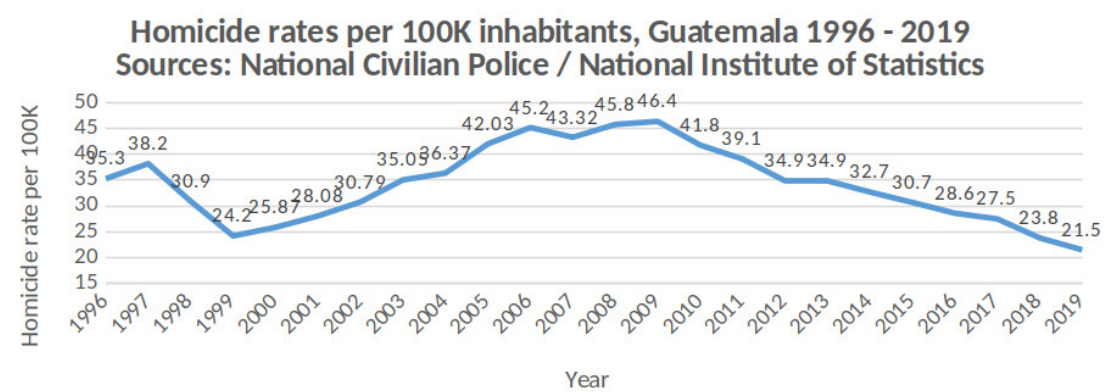

Figure 1. Homicide rates per 100K inhabitants, Guatemala 1996-2019.

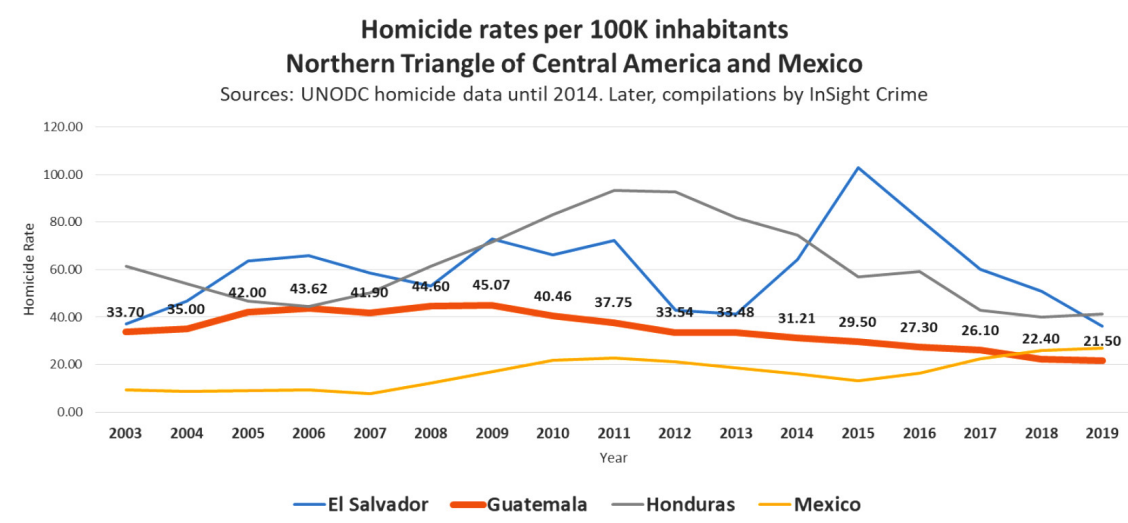

Figure 2. Homicide rates per $100 \mathrm{~K}$ inhabitants Nothern Triangle of Central America and Mexico.

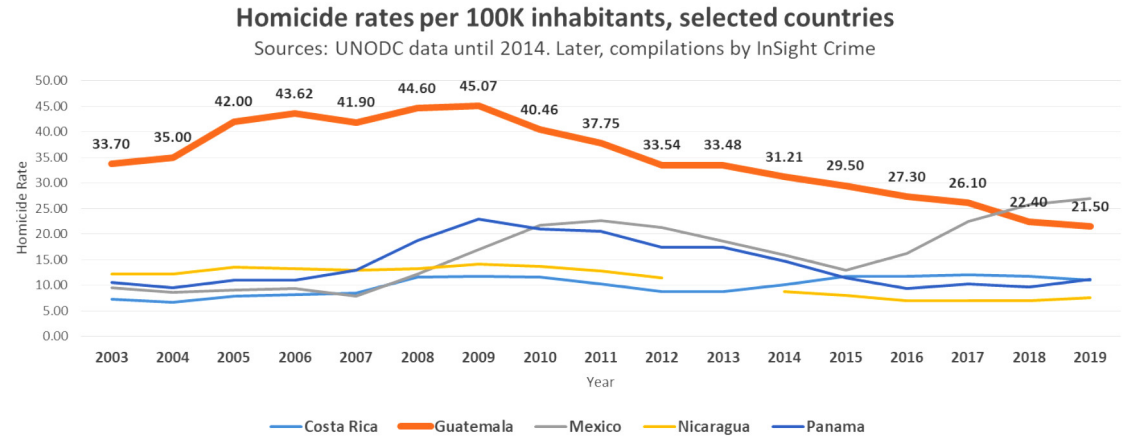

Figure 3. Homicide rates per $100 \mathrm{~K}$ inhabitants, selected countries. 


\subsection{From Counterinsurgency to a Mafia State, and the} Police's struggle to keep up with the Transformation of Violence

During the Guatemalan internal armed conflict, military intelligence officers devised schemes to fund their repressive operations tapping into state revenues from customs duties and other sources. These clandestine structures, or CIACS [8], as they came to be conceptualized in the peace accords, expanded into transnational criminal activities and crucially permeated security and justice institutions, including the police. They were able to exploit state structures, wield violence to further their interests and ensure impunity for their acts. By the end of the war the operation of these "hidden powers" led Amnesty International to label Guatemala as a "corporate mafia state" [9].

Denunciations of the massive violations of human rights that were being committed by the military in the 1980s eroded international, and crucially United States (U.S.), support to the Guatemalan government. Rifts within the army leadership led to a coup d'état, that opened the way for an elected assembly that sanctioned a new constitution in 1985 and the eventual election of a civilian, Vinicio Cerezo, as president. The long process of peace negotiations that ensued reached a definitive peace accord in 1996 which mandated cutbacks on military power and created the new police force.

The nascent National Civilian Police (PNC) faced difficulties in setting up its education model. President Alvaro Arzú(1996-2000) brought the Spanish Civilian Guard to train the PNC but international experts in the United Nations humanitarian mission in Guatemala (MINUGUA) disagreed on his choice. Other international donors became involved in providing support for police training, which gave rise to disparate results and a lack of clarity in the education model for the PNC. Problems in recruitment and mismanagement let conflict-era state security agents join the new PNC, delaying the pursued severance with the repressive approach to security. New recruits received short training courses, only three months long in some cases, and were paid low wages.

During President Alfonso Portillo's administration (20002004) the CIACS transformed into mafia organizations, engaged in national and transnational crime for private profit and continued to extend their reach, attaining influence over the processes of appointment of magistrates to high courts and illegally financing politics. Portillo frequently replaced police chiefs and interior ministers and drastically cut the police academy's budget. Hardline measures against street gangs included arbitrary massive incarceration that alienated poor youth and allowed gangs to expand their extortion networks while concentrated in prisons from which they began to operate regularly making use of homicidal violence to enforce their villainous dictums. Criminal investigations and crime prevention capacities in the police remained backward.

Under President Oscar Berger (2004-2008) the rising trend in homicidal violence accelerated and the PNC's image plummeted. Members of the police were revealed to have been involved in the prominent murder of Salvadoran parliamentarians in Guatemalan soil in 2006, allegedly in a drug trafficking deal gone wrong. Accusations were lodged against the Minister of the Interior, the Police Chief and other high-level security sector authorities for extrajudicial executions in prisons and "social cleansing" campaigns in poor neighborhoods. Under the pressure from international donors that these events brought about, Berger approved the creation of the International Commission against Impunity in Guatemala (CICIG).

Originally proposed by human rights defenders to investigate CIACS' attacks against them, the UN-backed CICIG started operations in 2007. CICIG was set up as a hybrid investigative unit able to co-prosecute with the Attorney General's office through the mechanism of "collaborative plaintiff". It pushed forward legal reforms that authorized the use of special methods of investigation, including wiretaps, which produced crucial evidence for its cases. During its 12 years of presence in Guatemala it helped to develop national capacities to investigative and prosecute crime, including in the police.

President Álvaro Colom (2008-2012) created a Police Reform commission and appointed Helen Mack, a prominent human-rights defender, as chief. She set out to introduce a police doctrine to break from the inertial tendency towards a militarized approach, but low budgets hindered the modernization of the police academy [Interview with Helen Mack]. Although a meritorious effort, reformists in the police disdain the fact that an external entity was created to guide its own affairs [interviews]. Although efforts to develop police relations to the community were still insufficient by the end of Colom's government their institutionalization was closer.

The slow but steady process of professionalization of the police strengthened a group of reform-minded officers who pushed forward the development of what would become the MOPSIC. As Macaulay points out "when domestic actors do want police reform, long term results are more likely when it is driven by the police corporations themselves and not by politicians or technocrats [as] [p]olice pride in their own professionalism, encouraged both from within the institution and by policy-makers through training and performance management, is one of the best ways of reducing politicization and meeting complex security agendas" ([10], p. 185). Even if facing adverse conditions regarding political authorities' support for reform, it is also true that the Guatemalan effort to develop COP strategies benefits from the fact that it has included an in-house component.

CICIG became fully operational and its accompaniment allowed Guatemalan investigators and prosecutors to carry out their work with less fear. Under its influence, criminal investigation was prioritized as security policy to deal with the complex Guatemalan criminal landscape. Besides the contributions previously mentioned, the commission pushed forward the establishment of a witness protection program 
and tighter gun controls. The PNC developed its homicide investigations unit and opened up to collaboration with a progressive Attorney General, Claudia Paz y Paz, and Cl$\mathrm{CIG}$ in the implementation of strategic investigations aimed at dismantling whole criminal structures instead of using the traditional case by case approach. Making use of modern criminal intelligence analysis techniques, specialized software, and strategic penal prosecution, criminal actors and organizations that make systematic use of homicidal violence were targeted. International analysts consider the decrease in impunity these developments implied were crucial in allowing Guatemala to "buck the trend" of increasing homicide rates by the early 2010's [2]. Those years also saw the onslaught of gruesome violence from Mexican drug trafficking organizations (DTOs), notably the Zetas cartel, which sought to terrorize the public and governmental forces to control the drug trade in Guatemala. A series of coordinated actions, that included massive deployment of security personnel in northern municipalities, eventually ended the Zeta's systematic use of harrowing violence, if not their operation in the country, sometimes in collaboration with active members of the army and the police. Additionally, scores of criminal groups, mainly murderous extortion rackets, were broken up through coordinated action. Impunity slowly began to decrease and subsequently the extraordinary levels of homicidal violence began to recede.

Even if objective indicators of violence began to fall, it was by no means enough and the public's perception of insecurity continued to grow. This was a major factor in the election of Otto Pérez, a retired army general, as president (2012-2015), whose campaign centered on the promise of a "strong fist" against crime [11]. The UN Secretary General appointed a new CICIG commissioner, Colombian Iván Velásquez, in 2013 after Pérez requested the previous one to be replaced. Once in Guatemala, Velásquez carried out wide consultations to understand the specificities of the domestic criminal phenomena. Velásquez's analysis pointed towards the need to prioritize investigations against corruption as he considered it to be the main mechanism through which the CIACS sustain control over the state and procure impunity for their criminal actions. This was a crucial recasting of CICIG's strategy that would very soon produce striking outcomes.

In April $2015 \mathrm{CICIG}$ and the Attorney General revealed a case of tax fraud in the customs agency that involved the Vice-president's private secretary. Massive rallies against the government broke out through the country, at which the police remained respectful of protesters' rights and democratic order. Additional evidence confirmed the public's suspicions of involvement of the highest authorities. It led to the indictment of the Vice-president and eventually forced the resignation of President Pérez in September of that year. Pérez, his vice-president and scores of members of his cabinet face multiple charges of corruption in Guatemalan courts at the time of this article's publication. The "Guatemalan Spring", as these events came to be referred to, showed that all members of Guatemalan society, no matter how powerful, can be subjected to the law; that citizen mobilizations can achieve changes at the highest levels of government and that justice and security institutions have the capacity to carry out their missions even under very difficult conditions, if provided with the necessary support.

In this context the public reacted against traditional politicians by electing Jimmy Morales as president in 2016, a TV comedian, who ran under the slogan of "not corrupt nor a thief". Unfortunately, a cabal of former-military officers with links to CIACS and bent on fighting-off justice processes for crimes committed during the armed conflict, was behind Morales' candidacy who, although a new face, was not a reformer of Guatemalan politics. After CICIG presented charges against Morales' brother and son in a corruption case, the president full-heartedly joined powerful members of the elite in a backlash against CICIG and refused to extend its mandate, which ended in September 2019. Furthermore, Morales took a militarized hardline in matters of security removing career officers from the top echelons of the police as part of his move to weaken the collaboration among national institutions and CICIG in the fight against corruption. Guatemalan society was unable to channel the resentment against grand corruption into sustained momentum for political and police reform. During Morales' administration (2016-2020) the "hidden forces" were able to take back lost ground.

\subsection{Community Oriented Policing as an Opportunity to Further Police Reform}

Even though reform has not taken hold of the Guatemalan political system as a whole, the recent events narrated above have allowed certain positive dynamics to develop at the level of the institutions. A priced accomplishment is the enhanced collaboration between police investigators and Attorney General's prosecutors which is arguably the main reason behind the steep decline in homicidal violence since 2009. Enhanced capacities for crime investigation have promoted professionalization within the police that open up possibilities to consolidate a preventive approach to security by developing its capacities for community-oriented policing.

COP means different things in different contexts but can generally be conceptualized as "full-service personalized policing where the same officer patrols and works in the same area on a permanent basis, from a decentralized place, working in a proactive partnership with citizens to identify and solve problems" $[12,13]$. It can generally be considered functional to police reform in that it "marks a shift in emphasis [...] from reactive to preventive policing [...], from the police as representing external coercion to police embedded in and working in partnership with communities" [13].

Attempts have existed within the PNC to introduce COP strategies since its first years of operation. A Subdirectorate General for Crime Prevention (SDGPD [14]) was formed in the 2000s and specialized in working with children, women, multicultural issues and fostering community relations. Programs have included door to door visits 
to neighbors, presentations in schools, liaising with traditional authorities, and supporting local citizens' committees. Notable was an interinstitutional "Safe Schools" program that kept educational premises open after-hours and during weekends providing instructive and recreational activities for young people [15]. These programs did not become permanent in the institution, but provided experience and stimulated discussions which, encouraged by donor support, led to consequential developments.

The PNC launched its most serious effort to date to institutionalize a preventive approach to security by sanctioning the Integral Community Security Police Model (MOPSIC, its Spanish acronym) in 2014. Its manual formulates the MOPSIC as "[...] a model inspired on the community policing philosophy and police doctrine, oriented to provide a quality service, based on timely and effective attention to citizens' demands for security and coexistence, starting from the assignation of direct responsibilities to a work team over a specific area to carry out prevention, dissuasion, response, investigation and analysis activities. The model is supported by new information and communications technologies that will assist in improving the management of police services in an integral way. Its general objective is to foment the professional capacity, police effectiveness and trust relations with the community, to optimize police service, reduce violence indicators and contribute to citizens' peaceful coexistence" [16].

The MOPSIC sets out the values, norms, and contributes tools for police practice to serve societal needs. It provides guidelines to carry out all major aspects of policing from a perspective that is respectful of human rights. It crucially introduces COP into the language and practice of the PNC assigning responsibility for crime indicators to officers in charge of demarcations and provides data gathering tools to design strategic approaches in different situations of crime and violence.

A strength of the MOPSIC model is that it was developed with direct participation of the planning office of the PNC, contributing to its appropriation on the part of the police force. It is aligned to the political and legal framework of the institution. Implementation of the MOPSIC model was included in the PNC's Strategic Plan 2014-2020 and Government Decree 48-2014 reorganized stations and substations to respond to it. An institutional-wide effort to train all units to adapt to MOPSIC principles has been in place since its inception, admittedly with limited reach. The Subdirectorate General of Studies and Doctrine is in charge of mainstreaming MOPSIC into all police praxis, but its introduction into the police academy's syllabus has not fully been realized yet.

The MOPSIC manual's tools to study the situation of crime in assigned districts include the Integral Format of Police Activities (FIAPOL), that is used to plan work periods, and the Statistical Analysis Format (FAES), used to summarize and determine the security situation in a particular territory. Each of the existing 130 stations are supposed to have at least two analysts that compile and verify infor- mation (not all of the 512 substations do, but stations cover the same territory). With this information they formulate a diagnostic of the security situation and plan responses according to the level of gravity and resources at hand. The strategy chosen may be mainly preventive, reactive or investigative in character. By 2020 all stations had an information system of this kind in place, but the degree of actual implementation was not clear. Internet access continued to be a big problem, which leads the police to favor the use of off-line formats to save and share the data.

The SDGPD has been the champion for preventive approaches to security within the PNC since its creation in the mid 2000's. Its personnel carry out specific activities with local organizations, but it is not them who are directly in charge of the security situation in the communities. That is the much larger Sub-Directorate General of Operations (SDGO) which has only slowly adopted MOPSIC as it is permanently under the pressure to provide results in matters of crime busts. The creation of a unit of "MOPSIC facilitators" to train personnel in the substations to deal with the need to encourage adoption of the model within the SDGO caused some confusion as its functions overlapped with SDGPD's own Directorate of Community Relations (DIRC).

The PNC set up a team that included members of different parts of the institution to evaluate the initial implementation of MOPSIC. It showed that only 25 per cent of substation in the Central District, where Guatemala City and its metropolitan area are located, had been trained in the MOPSIC manual by 2017. A new institutional assessment effort was being carried out during 2019, but President Morales' obstructionist turn effectively halted the process hindering the expected reforms.

The donor community has backed preventive strategies in the police through the years, including the development of MOPSIC. The U.S. has provided the largest amounts of financial support through the Bureau of International Narcotics and Law Enforcement Affairs (INL) and the United States Agency for International Development (USAID). The Japan International Cooperation Agency (JICA) has provided continuous technical support to the development of COP in Guatemala including by training educators and higher-level officers in Japan and Brazil since the 2000s. Other important donors to the police include the Spanish Agency for International Development Cooperation (AECID), the German Federal Enterprise for International Cooperation (GIZ) and the United Nations Development Program (UNDP).

Although the basis for a new understanding of policing in a democratic context is in place, patchy knowledge, high turnover, and low trust encumber MOPSIC application. The post-conflict context of Guatemala is not ideal for the implementation of COP. The stakes are especially high in metropolitan areas where homicidal violence, extortion schemes and threats to physical integrity or life, mainly coming from street-gang members, are common. If the permanent preoccupation of violence impacts police officers in the United Kingdom, a country with one of the lowest homicide rates in the world, in Guatemala, the "working per- 
sonality" of police officers is greatly affected by the stress caused by potential violence. COP in Guatemala must take into account its rich cultural diversity. Police agents and officers have to adapt the general guidelines in the MOPSIC manual to the specific conditions of social organization in places of implementation. Inter-cultural considerations were not part of the original design and police agents are scarcely trained in it.

Our research set out to identify the difficulties and the opportunities that exist to further the implementation of COP in specific territories. The material and methods for the study are presented next, together with a description of the sites of research and the criteria used for their selection.

\section{Material, Methods and the Sites of Research}

Research began with consultations and exploratory visits to National Civilian Police sub-stations in Guatemala City and La Antigua. Initial information and analysis were discussed in seminar-type meetings with experts, institutional authorities and representatives of international donor entities during which the interest in studying the implementation of the MOPSIC in contrasting contexts was defined. Even though the police aspires to apply the same policies, instructions and manuals in all its stations in the country, the results vary significantly from place to place with regards to mechanisms of institutional articulation, police-community collaboration and impact on security levels.

Qualitative sampling methods were used to identify Villa Canales and Totonicapán as the sites for field research (Figure4). Both were localities where the PNC was already implementing MOPSIC but with very different attributes relating to violence levels and social organization. Three rounds of visits to each of the sites to carry out structured and semi-structured interviews, participant observation and focus groups took place from February 2017 to May 2018. Rounds of interviews with experts and authorities transpired throughout the period of research until August 2019.

Access to consult the local community in Totonicapán required informing and obtaining acquiescence from the "48 Cantons" traditional indigenous organization. In Villa Canales no special approval was required. Authorization to interview members of the police precincts in Totonicapán and Villa Canales was obtained through the PNC Sub-Director General for Crime Prevention who personally spoke with the officers in charge in the territories to ensure our access.

Villa Canales is a metropolitan municipality in the vicinity of Guatemala City that has experienced disorderly urban grow, which has produced a demographically dense district with uneven social organization. Villa Canales is one of the most violent municipalities in the country with a homicide rate of 37.0 per 100,000 (in 2019). Both main street gangs (MS-13 and Barrio 18) are active in parts of the municipality. Street robbery, usually violent, is common. Local narcotics traffickers provide a kind of protection to the people living around where they operate as in those places "there are no thieves, the thief that shows up, dies" and [Sub-station chief in down-town Villa Canales].

Villa Canales is part of the police district under responsibility of Precinct 15 (Comisaría 15) which also covers the neighboring municipalities of Villa Nueva, Amatitlán and San Miguel Petapa, each with one station and a total of 18 substations to serve a population of 841,314 [2019 Census Data]. Approximately 60 per cent of the 40,000 members of the police work in the department of Guatemala where three million people live; only 22 per cent of the population, but also the place where most of violent crime occurs. Despite the concentration of human resources in the metropolitan region, personnel is still insufficient for patrols to cover permanently all of the territory. Villa Canales, having the largest area of all municipalities in the department of Guatemala, has distant villages that are hard for the police to reach. In those places the PNC has established agreements with local authorities for them to carry out surveillance activities and inform the police if a problem comes up.

Totonicapán is a municipality in the western highlands of Guatemala with urban and rural localities, low levels of criminal violence and strong indigenous communal organization. Situated 179 kilometers away from the capital, it is a relatively autonomous region where traditional forms of indigenous local governance prevail, and where the community demonstrates a clear ability to hold the police accountable. Totonicapán is one of the most peaceful municipalities in the country with a homicide rate of 2.4 per 100,000 in 2019.

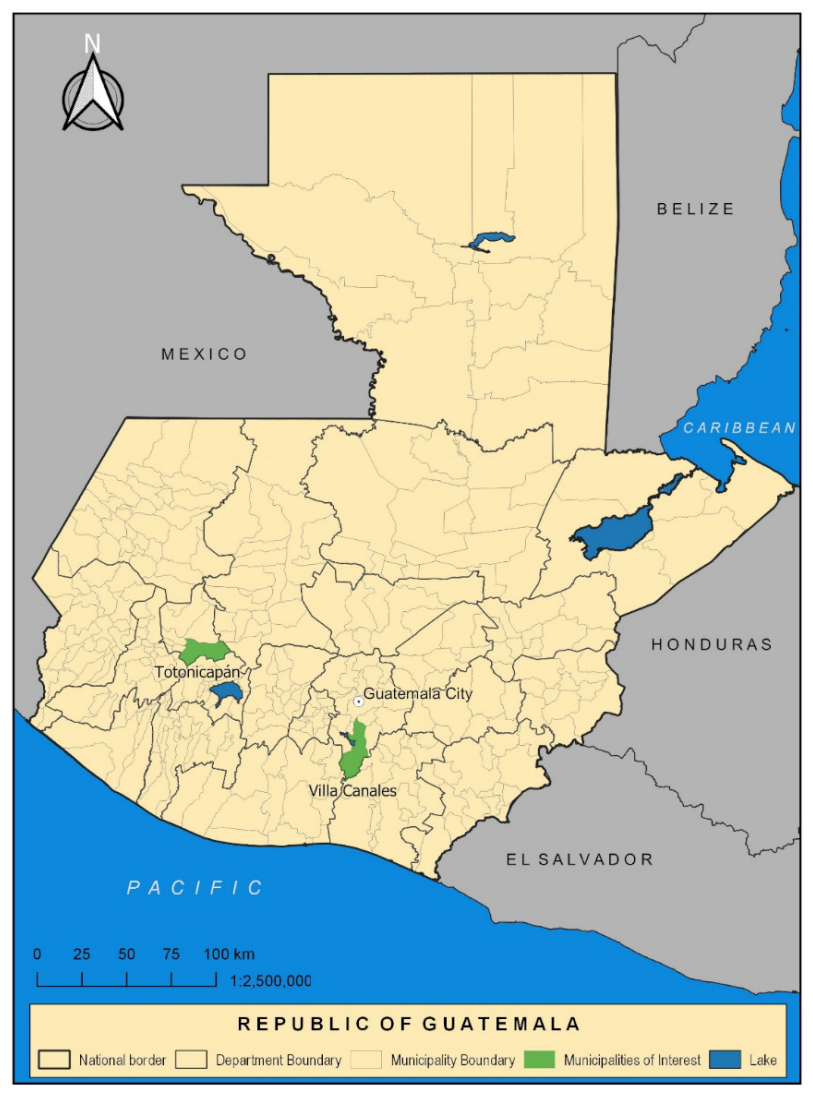

Figure 4. Position of the municipalities sites of research. 
The eight municipalities that compose the department of Totonicapán are under the responsibility of the PNC's precinct 44 . The population of 418,569 is predominantly rural and indigenous [17]. The precinct has 3 stations and 10 substations where 375 police people work, 43 of them are women. The personnel is divided into three groups, which work 7 days and are off during 4 days. The two active groups relay service every 8 hours. The work force is insufficient to patrol the large territory in which many villages only receive occasional visits from police patrols. Totonicapán consistently shows at the bottom of the national crime ranking. Homicide is exceptional in the department, but domestic violence and land and water conflicts are common. In Totonicapán the police, and all other national institutions, must coordinate their actions with the strong local governance structures that are the de facto administrators of the territory.

Totonicapán has proved extraordinarily capable of keeping away from the violent dynamics that have engulfed most of the rest of the country throughout its history. During the internal armed conflict the western highlands was the region most affected by military-perpetrated scorched-earth strategy against the civilian population. Totonicapán was a relative island of peace, affected by only one of the hundreds of massacres that occurred from the late 1970's to the early 1990's [1]. The strength of Totonicapán's traditional governance institutions is credited for its communities' capacity to avoid involvement with the guerrillas and to fend off military encroachment [18].

Its proud history of resistance against the imposition of external rule from Spanish colonialists and later from the Guatemalan republic has preserved indigenous forms of local administration. Indigenous authorities were officially relegated to a second plane in the 19th century, however, in Totonicapán, as in some other places in Guatemala, the indigenous or "auxiliary mayors" continue to make most of the decisions in villages, cantons and neighborhoods. An assembly composed of the local representatives, termed the "48 Cantons", confers, negotiates and usually reaches agreement with official Guatemalan state authorities, including the National Civilian Police. The 48 Cantons administrate justice in cases of lesser gravity and mediate conflict among communities and individuals [19].

All major local political decisions are taken by the 48 Cantons. It enjoys legitimacy among those it rules as it is based on principles that originate in their Maya indigenous world view. Its authorities are chosen for a limited period of time and officiate in a spirit of service. They cease their usual labor and the community provides for the material wellbeing of their families during their time in office. The official-system mayor, who is elected in the national elections, exists, but his functions are limited to matters of infrastructure development and management of a municipal police body.

\section{Results}

"Structures are important, but the substance of policing lies in the rules, norms and values that guide police activities on the ground" [20]. The MOPSIC in Guatemala intends to provide that needed guidance, but a long way to go remains for its adequate application. An in-depth assessment of MOPSIC implementation in the territories of research follows, for which the four basic elements that Frühling indicates define COP are used. These are: 1) Police activities are planned and carried out focusing on a small geographic area; 2) strong relationships are established with the community to facilitate an ongoing consultation process with citizens and to ensure that their perspectives are considered; 3 ) the police focusses on solving concrete security issues affecting local residents, instead of simply reacting when a crime occurs; and 4) the police is involved in determining the conditions and circumstances that favor offences perturbing the daily life of residents and a course of action to overcome them [4]. The section ends with a consideration of the conditions for police accountability to develop and to foster trust in the relations between the police and community.

Criteria \#1: Police activities are planned and carried out focusing on a small geographic area:

Most police people interviewed in Villa Canales said they had heard about the MOPSIC and understood it implies a change in the overall orientation of their work towards meeting the security needs of the population they serve. However, few of them had been specifically trained to implement the manual. Even so, operational (SDGO) agents implement on-foot patrols in limited areas of the central urban parts of the municipality. The routes for patrolling are assigned to couples of police people for each of the 8-hour periods they must be active. The agents visit local shops and are ready to speak to the public, but it is prevention (SDGPD) agents who continue to carry out the talks at schools, churches and other local organizations. PNC respondents indicated that their capacity to cover more territory is limited by a lack of personnel. Other local authorities interviewed confirmed this opinion.

In Totonicapán the situation is similar, with patrolling routes established and visits to local institutions. During market days in Totonicapán the police patrol on foot and on bicycles together with personnel from the municipal police while a control room monitors surveillance cameras.

International cooperation projects have provided support for the development of these initiatives in both municipalities, including setting up surveillance systems of closed-circuit cameras in the urban centers. Even if not all agents are specifically trained for the implementation of the MOPSIC manual, observation carried out in both municipalities permit to assess this first criteria in an acceptable level. The focus on small geographic areas is expected from the police and there are instruments to guide its implementation.

Criteria \#2: Strong relationships are established with the community to facilitate an ongoing consultation process with citizens and to ensure that their perspectives are considered:

In Villa Canales station chiefs carry out formal meetings with the mayor and his municipal council to report on the situation of crime and the actions the police have taken. 
Meetings with the wider municipal development council (COMUDE), which includes community leaders, occur only occasionally. At lower levels police agents reported they do carry out more frequent meetings with community development councils (COCODEs) in the urbanized parts of the municipality. The meetings are usually called for by the local participatory organizations to forward requests which, if necessary, are escalated to the municipal-level meetings. Operational police agents usually share their personal mobile telephone numbers to communicate directly with local authorities.

Research detected that operational police people don't have sufficient training or tools with which to participate proactively in these community spaces, but the communication channels are open to respond to emergencies. Villa Canales residents interviewed for this study confirmed that the police meet with the community and that they listen to what they have to say even if they "are hit with a stick"' when receiving criticism. Other signs of improved policecommunity relations found during the research include the carrying out of benefit activities that raise funds for the police. In 2017 the funds were used to repair the stations' motorcycles.

Strong collaboration does take place with the municipal police. This doesn't occur everywhere, as it depends on the mayor's willingness to take on security responsibilities. PNC agents expressed they feel supported by this collaboration as municipal bodies enjoy public acceptance and can contribute vehicles, mainly motorcycles, that allow couples to carry out joint PNC-Municipal Police patrolling and cover parts of the territory previously beyond their reach [21]. They participate in potentially difficult tasks such as enforcing limits to the hours during which alcohol-selling shops can operate and provide breath tests that the PNC doesn't usually have. Although part of an elected body, the municipal police is not representative of "the community" in itself. Taking these elements into consideration, it can be said that there is a basis on which to develop further the implementation of criteria \#2, although at the time of research it was operational in Villa Canales only at a passable level.

The case is quite different in Totonicapán. The PNC and other national institutions present in the department, which include the Attorney General's office, courts of law, and the Indigenous and Women's Defense office, meet on a monthly basis with the 48 Cantons, the local governance structure. Communication is permanent among both sides. In the meetings the state institutions provide reports on their activities and receive requests from the indigenous authorities. The 48 Cantons control community surveillance and preside the technical council on security.

The police's work is contingent on the authority and conflict resolution mechanisms of the indigenous governance structure. In a case of domestic violence, for example, the aggrieved woman calls on the deputy auxiliary mayor, who summons the husband to a communal session. Community members can attend and intervene during the hearing while the deputy mediates to reach a conciliatory agreement be- fore the auxiliary mayor makes a decision. The police are many times present in the meetings, but await the local assembly's resolution, "... sometimes we are there but it is as if we weren't because the people say: no, the auxiliary mayor is the one in command here" [female police officer in Totonicapán].

Members of the police interviewed acknowledged that their support is requested by the community only when their own mechanisms have been surpassed in their capacity to resolve conflict. In such cases the police is called in, and if necessary, asked to detain the accused person. The police carries on from there in accordance to national legal procedures. A justice-sector officer interviewed in Totonicapán values the collaboration, "[the traditional authority system] is effective. It solves cases in a considerable amount. If they were not here, surely our work would be much harder"'.

In some rural communities in Totonicapán the police are not invited to participate in local conflict resolution processes at all. The police accepts these arrangements. "We have been respectful of their decisions to avoid increasing tensions with the community" [Police Commissioner in charge of Totonicapán's departmental station]. Nevertheless, when the cases involve situations of serious violence, like rape or injuries, the local authorities yield to the national official system of justice.

The main apprehensions of the police have to do with the risk of not being able to control a situation in which the community takes "justice into its own hands". Events such as lynching of accused subjects have happened in the past. At times, mobs, unsatisfied by the police's effort to preserve suspects' physical integrity, have targeted the police itself. But in general, police respondents expressed that communication with community leaders has improved with the implementation of the MOPSIC. This has been a contribution for the communities to respect the rule of law, allowing police people in Totonicapán to feel safer than before.

Indigenous organization mechanisms together with MOPSIC implantation have fostered mutual respect and tolerance. A traditional authority in Totonicapán informed that, "this year [the police] have provided support in all what's necessary and their treatment towards the population has improved. Ten years ago, the police produced fear in the community. The service is now more open, they have a higher academic level, they are trained and practice good human relations. The treatment towards the people has improved as called for in the peace accords and the [ILO's] Convention 169" [Communal authority]. The research revealed good opinions towards the police even regarding gender-based violence. "Regarding violence against women I perceive [the police] has good knowledge, they are sensitized in that aspect. [...] I know of no woman who has complained about it" [female local leader].

An independent party, the officer in charge of the Attorney General's office, corroborated that the police are knowledgeable of international instruments such as the ILO's 169 convention and express respect to the rights 
of indigenous people based on it and on the Guatemalan constitution. He indicates that despite the usual difficulty in getting people to collaborate in national justice system cases, most of which have to do with domestic violence in Totonicapán, they are now more open to collaborate with the police. "The improvement has not been dramatic but is certainly visible" he said [local national officer].

Ceding some of its control to indigenous leaders may raise concerns of possible marginalization of the police from indigenous communities posing problems for individuals to access the rule of law. Political anthropology has pointed out that "state sovereignty [...] is being contested in new and different ways as the boundary between state/non-state in the exercise of clandestine and illegal forms of violence becomes ever more blurred" in Guatemala [22], pp. 17-18). But as long as mechanisms exist to "improve coordination between community authorities and state justice officials [a] wider struggle to secure recognition of indigenous autonomy, to guarantee indigenous peoples' collective and individual human rights, and to limit violent community responses to crime" may be at work [22], pp. 17-18). Our research identified that MOPSIC is beginning to provide a previously inexistent mechanism to develop such coordination.

In general police people value highly the change MOPSIC has brought about in their approach to the communities. A departmental PNC authority considers the opening up of communication between the community and the police "... to be the central axis of how to work, there is no other way to go now" [Interview PNC authority in Totonicapán].

Nevertheless, as in Villa Canales, only some of the police officers interviewed have gone through training for the implementation of the model and not all were knowledgeable of MOPSIC as a cross-cutting philosophy for police work. Even so, the fundamental orientation towards providing service to the needs of the community can be perceived in the descriptions police interviewees provided of their duties and their conception of their work. A Totonicapán policeman shared his understanding of the new attitude the police must pursue as "carrying out police activities with a clear thought of providing help to the citizens in the first place and developing trust in that way from the citizen who will then provide the police with information to be used in prioritizing the needs for prevention, investigation and control of crime" [Interview PNC agent in Totonicapán].

Overall, the implementation of criteria number 2 can be positively assessed in Totonicapán. Relations with the community there can be said to be strong because of the need of the police to coordinate closely with the local governance structure to be allowed to act. The PNC respects the preeminence of the local system of authority over its own and citizens' perspectives are definitely considered. As in Villa Canales, though, the police's participation has a way to go to become more proactive.

Criteria \#3: The police forces focus on solving concrete security issues affecting local residents, instead of simply reacting when a crime occurs:
The National Civilian Police has the knowledge and capacity to carry out sophisticated actions to deal with security issues that affect well-defined areas. Task forces have been established to identify and focus on high-incidence communities where PNC experts interviewed have identified criminal profiles, patterns, and structures, that have allowed them to put together actions to prevent crime exante based on criminal analysis. But these efforts have remained limited experiences in certain places such as Champerico, Chiquimula, Retalhuleu, and some zones of the metropolitan area of Guatemala City. They have not become sustained, institutionalized efforts.

During research, only limited development of this criteria was observed in either of the municipalities, although there is a clear understating of the need to do so. Respondents acknowledged that the positive results in the reduction of homicides that Villa Canales has achieved are owed to the PNC's strategy of posting police couples permanently at hot spots where their analysis of past occurrences indicated most killings took place. In Totonicapán the police credit the combined use of technology and an accompanying communication campaign with an increase in security measures taken by the population such as locking car doors and closing windows that achieved an important decrease in car theft in the municipality. These are valuable examples, but this kind of practice is not yet implemented permanently nor throughout all of the national territory.

Criteria \#4: The Police is involved in determining the conditions and circumstances that favor offences perturbing the daily life of residents and a course of action to overcome them:

The MOPSIC manual provides the FIAPOL and FAES tools to plan work periods and to gather information about the security situation at the local level, but the persistence of militarized approaches to the management of data harms the implementation of these useful new instruments. The way in which information management protocols are set up in the PNC make it very difficult for police people at the station level to be able to make systematic use of the information they retrieve. The data goes through a convoluted process of reporting upstream in the institution. Each of the 133 stations produces "circumstance reports" (informe circunstanciado) three times a day for the precincts, all of which send a daily consolidated report to Guatemala City headquarters. There, the Novedades unit assesses the reliability of the information received, usually based on the existence of a geographic reference for the events and makes a decision if it becomes a "novelty report" (informe de novedades) or not. This information then reaches the PNC's Chieftaincy of Planning (JEPEDI [23]) which enters the information into its data base. High-ranking officers interviewed acknowledge that much information is lost along the way and that reports are produced for the almost exclusive consumption of the highest command. This compartmentalized approach to information management reflects the persistence of military-era practices in the police common in other countries of Hispanic heritage. Exclusion from in- 
formation and knowledge are used as ways to accumulate personal power. The cultural change it calls for will not come about soon or easily.

Basic crime analysis products would increase the capacity of the police in the municipalities to prevent crime. At the time of research mechanisms to deconcentrate the process and provide information products to the field stations were not being implemented. A police expert at one of the research workshops said that he had heard station agents refer to the use of the data gathering tools as having to "fill out the little pages" without much conviction. Even if they produce data, police at the station level are not systematically making use of it to plan crime prevention strategies, much less together with the residents. Police staff at the municipalities studied were mindful of the importance this would have in strengthening their accountability mechanisms towards the population but appeared incapable to change the situation on their own. This fourth criterion for COP assessment was found to be the weakest in the sites where the investigation took place.

\subsection{Accountability, Trust and Respect in Police-Community Relations}

At its most basic, police accountability has to do with the existence of information on the situation of crime and violence at the local level and the capacity to respond directly to the security issues that the community faces. It is increasingly common for the National Civilian Police to inform about its activities to the different levels of communal organizations (social development councils at the departmental, municipal and at times at the community level). The councils, though, frequently ask for things from the police that it can't provide, such as dedicated patrol shifts, more vehicles and public surveillance systems.

The lack of resources and the need to prioritize cases based on their gravity are the main reasons why police officers say they fail to respond quickly to requests. In both municipalities the principal material limitations that the police faces have to do with un-serviced patrols that break down, insufficient amounts of fuel to have permanent mobility, and unstable access to the internet in stations and substations. Agents reported that having the permanent possibility to search the internet to find addresses or to send information would benefit their work significantly. Civil society members in Villa Canales acknowledge the situation. "The problem is that [police officers] aren't even issued a telephone. They use their own. I have the officer's number, and if I call him, I am sure he will answer" [Community leader]. They are also cognizant of the rough conditions of stations and substations where the police personnel eat and sleep. They perceive this as a vulnerability that may entail security risks. If the institution is not providing decent working conditions, some elements of the personnel may become susceptible to lure from criminals.

On average, communities reported middling levels of trust in the police, but acknowledged this to be an improve- ment from five or ten years ago. Those who expressed the traditional mistrust towards the institution usually had less direct relation to the police. They tended to consider insufficient the efforts that the PNC carries out to approach the population pointing out that not all police people are well informed, trained or motivated to carry out a COP approach. Even in such cases the informants recognized that a few notable incidents of police misbehavior affect the whole of the institution disproportionately. The police resent the bad reputation that "a few black sheep" have created for the institution as a whole.

Police interviewees blame lack of crime reporting from the community to be a central obstacle to their work. Many people, after the police has responded to their call and arrested the suspect, fail to follow through with the formal complaint. Even if for understandable reasons, that is the cause for which many suspects go free soon after being detained. This notwithstanding, they also expressed that the incipient levels of trust that are being developed have allowed access to information in certain cases that would not have been possible before.

Even though levels of trust are still low, members of the community recognize that the limitations with which the police operate affect the results of their work. "People have little trust in [the police], but it is because many don't know the penury they endure and the situations in which they can intervene and those where they can't. The police do its work and do all they can. But, in the event of a theft, they grab the thief, but the thief has nothing on him of what he's accused of having stolen. The judge can't accuse him of anything and lets him go. And who is to blame? The police! And it's not them to be blamed. There are ways to understand why things happen" [local leader in Villa Canales].

Those that are part of community organizations such as the Municipal Commission for Violence Prevention (COMUPRE) or the Network of Derivation of victims in Villa Canales have had the opportunity to collaborate with the police more closely and showed more appreciation of improvement in the police's attitude and capacities. Civil society members in Villa Canales recognize that the disorderly urban growth of the municipality has increased risks of crime and violence, making the police's work much more difficult in recent years. A local leader in Villa Canales says: "They are overwhelmed, they want to, but they can't, the population doesn't allow them to. Now I feel that the lack of credibility in the PNC affects them" [Member of civil society in Villa Canales].

On the side of the police, the research frequently found motivation to foster the orientation towards the community. Police respondents value the possibilities that increased contact with the communities allows them to convey the reasons for their inability to respond with the speed that the population wants. "I can explain to the man or woman at the meeting that my sector has only one vehicle to patrol..." said a police officer in Villa Canales. An operational agent shared his enthusiasm about the improvement in the relations with the community, "we feel like super-stars when a 
child says hello to us and says he wants to be a policeman when he grows up. [We] are changing the perception of rigidity, our actions allow the citizens to believe in the police, to trust it, and that translates in the people telling us what is going on, and so we can act and solve their problems. [...] We have changed, from repressive police into a friendly one, into a community police with international standards that we will pursue as we reach maturity as an institution. We are only 20 years old, an adult age, but more years are needed, and we can continue to improve" [Operational agent in Villa Canales].

Even administrative police personnel in Totonicapán understand their work contributes to the overall objective of closer cooperation with the communities served. An officebased female police agent shared that, "in the administrative area we set in each weekly plan [for operational personnel] visits to at least three parishes, three commercial sites, three public schools, three private schools and three banks or companies. This makes me 'communitarian' because I am providing strategies for our personnel to reach out into other municipalities for all of us to work in harmony" [administrative agent in Totonicapán].

The research shows that the opportunity exists for local community organizations, such as the COMUPRES, to become stronger in pressuring police officers in charge to carry on with good planning and joint implementation that has existed. "We have seen that if we let the police on their own it is total chaos, but if we are friends with them, if we become strategic allies, putting pressure on them, motivating the people to report, we can achieve much" [civil society leader in Villa Canales].

This is what happens already in Totonicapán, where the police willingly yield its authority to that of local traditional governance structures. It would be too much to ask from the PNC to develop from this an integral multicultural approach to policing in the short-term, but the foundation to ensure that the attitude is not one of mere tolerance due to relative weakness, but effectively one of intercultural respect, is already in place. The fact that those that have worked directly with the police have more nuanced opinions about the institution, even in the high-violence and disorderly context of Villa Canales, is an initial base on which to build stronger trust relations into the future.

\section{Discussion and Conclusion}

As previously acknowledged, political circumstances are paramount determinants of the possibilities for reform. Recent literature calls attention to the electoral disadvantage to officeholders and the complications from dealing with internal power structures that promoting police reform may pose [24]. In Guatemala, even though the police remain at the disposition of venal political elites, a "robust opposition" and "electoral counterweights" are not factors that determine reform outcomes. The old guard of officers trained during the conflict-era National Police is beginning to retire and with it resistance to reform. That very old guard, although it may have collaborated with criminal bodies such as the CIACS, didn't lead them. It never attained a corporative structure with specific interests to defend as in other countries.

Although ever-present, pressure towards militarization of the police has not overrun the institution. It is true military or former military personnel continue to be appointed to posts of responsibility in the security sector. But militarized policing strategies have come up in Guatemala when specific security situations have overwhelmed politicians urging them to provide a heavy-handed response. Army involvement in patrols ended in 2018 in compliance of conditions for aid set by the U.S. Congress. Moreover, Guatemalan society has not succumbed to the high degrees of punitive populism observed in neighboring countries. Law proposals to officially label street-gangs as terrorists and the candidacy of Zury Ríos [25], who ran on reactivating the use of the death penalty, have been unsuccessful. In spite of the heavy influence from the military, the PNC has been able to avoid complete overtake, not least through sustaining the effort to strengthen community-oriented policing strategies.

Bonner is right to point out that "[t]he authoritarian nature of policing per se and the protection by Latin American and Caribbean governments of highly inegalitarian societies specifically, stand against the prospect of COP being a flagship of societal democratization" [26]. There are times in which the inequitable social structure calls on state forces to control conflict for which the political system is underdeveloped to deal with. This happens when the police evict landless peasants from the holdings of agricultural industries or when protesters against the diversion of rivers are met with repression. At those times the police carry out the orders from the powers that be and act against the population if necessary. In such cases, the relation between the police and the community is completely adversarial and occurs in an impersonal manner. But those are extraordinary moments of intense crisis. As this research shows, the relation between the police and the community usually takes place under different circumstances in Guatemala. In Totonicapán the police are truly at the service of a well-organized community, and in Villa Canales the police are many times yet another actor under the same insecurity strains that the local population endures. At such local scale, a set of limited goals, like reduced crime, lower violence and peaceful coexistence can certainly be fostered through stronger collaboration between the community and the police.

In day-to-day life in Guatemalan municipalities, the police seem to be less alienated from the community than in other countries where formal COP program implementation is more advanced. Although the criticisms posed in the Ombudsman's national report regarding transgressions by the police are true and his recommendations valuable, it must also be pointed out that he has not had the need to call for extraordinary measures in containment of police abuse in recent years [27]. There is no identified trend in high-violence repression recurrently used by the police in Guatemala. This is in sharp contrast to Brazil or neighboring El Salvador, where processes of police 
reform are severely hindered by gruesome levels of police violence [28].

Guatemalan cultural diversity emerges as a special opportunity for COP. Alienation between the police and community is not complete in Guatemala. The respect or tolerance for local forms of governance that exists in places like Totonicapán could be turned into multicultural policing policy. COP provides the mechanisms for a joint consideration of what "security" can mean for both sides, so they become intelligible to each other and can agree on shared values such as peaceful coexistence, respect among groups, and also respect among individuals. Increased contact with the community to share information, analyze and plan together with the population and begin implementing COP strategies will contribute to increase accountability. When dealing with local-level security issues the opportunity exists for common understandings, goal setting and meaning to be constructed.

To expect text-book implementation of communityoriented policing strategies in Guatemala is like trying to make a silk purse out of a sow's ear. The force has remained understaffed, badly managed and insufficiently trained. It is a new institution that has existed in a context of political and criminal meddling in its affairs and overwhelmed with demands to deal with crime and violence. However, the improvement in matters of criminal investigation attained during the past decade and a half has developed institutional capacities, stalled the rise of impunity and dramatically brought down homicide rates. An undercurrent of champions for preventive approaches supported by international donors achieved the sanctioning of MOPSIC as institutional policy. Even if slow and incomplete, the implementation of the MOPSIC method is producing positive outcomes thanks to the improved communication and increasing trust levels from the citizens.

The development of criminal investigation capacities during the past 15 years in the justice and security sector spurred professionalism and has stimulated reform of the police, even if incomplete. Improved inter-institutional collaboration on criminal investigations is considered to be the main reason for the significant decrease in the homicide rate observed since 2009 in Guatemala. This momentous achievement shows that the police can be a part of positive change at the societal level. The opportunity to further police reform by developing the other main aspect of policing, crime prevention, is now open with the sanctioning of MOPSIC in 2014. Research results show that there is a basis on which to build stronger relations between the police and the community in Guatemala.

Professionalized officers, many of whom have obtained university degrees, are rising to leadership roles in the PNC. They have fostered processes of intra-institutional analysis that were the base for strategic plans drafted in the 2010's. They include many of the champions for the preventive approach to security that have appropriated the COP philosophy and were fundamental to achieve the sanctioning of MOPSIC in 2014. Although not a majority and working under conditions of scant resources and counter-reformist pressures, these groups are favorable to further develop public-centered approaches to security and are bastions against re-militarization.

Both former Police Reform Commissioners interviewed identified the need to dignify police people's working circumstances and increase their levels of education to achieve a better implementation of the new model. Mainstreaming the MOPSIC, not only in training new recruits in COP philosophy, but sustaining the effort to train active agents. In this, the Sub-directorate General of Studies and Doctrine, to which the Police Academy belongs, should take the leading role and contribute to develop the intellectual autonomy necessary to move away from the simplicity of military language and practice in the institution.

More must be done to engage the general public with regards to the importance of changing the repressive understanding of security that pervades Guatemalan society. Informing about what MOPSIC's objectives, planning and execution of projects and activities are can help to explain the changes in the philosophy and approach to policing that are taking place and prompt higher levels of trust and cooperation. This is to be understood as a long-term endeavor, but it may be the point of entry to the real fight for human security against repressive, authoritarian approaches of the past.

There are, of course, special challenges to be faced with regards to the penetration of organized crime in the police. Internal control mechanisms have proven incapable of eradicating corrupt practices. At the local level it has not been uncommon for mayors and local police chiefs to be involved with narcotics traffickers. It is very hard for police people to pass polygraph tests when asked if they have abused their positions at any time. These are very serious problems that affect not only the police, but by the whole of the Guatemalan governmental establishment. As described above, Guatemala has shown it is capable to respond to grand corruption when its public organizes, but this has only been possible when adequate international support has been in place as was the case during the existence of CICIG, which conservative forces effectively held back. The recent election of Joseph Biden as president of the United States is set to change the situation. He has given clear signs that the fight against corruption and the strengthening of democratic institutions will regain central importance in the relation between the U.S. and the Northern Triangle of Central America. This will include the establishment of new, smarter and more effective mechanisms to go up against corruption and renewed support to police reform, including, centrally, community-oriented policing.

The security situation is generally perceived not be deteriorating at this time in Guatemala. The professionalization of career officers, an increasing understanding of the philosophy of community policing and international support are the best chance to further police reform. These are elements on which to continue building on that the PNC and Guatemalan society must not squander. 


\section{Acknowledgments}

This research is a part of the Community-Based Policing and Post-Conflict Police Reform Project (ICT4COP). This project has received funding from the European Union's Horizon 2020 research and innovation program under grant agreement No 653909. I would like to thank the police agents, members of the community and experts in Guatemala City,

\section{References and Notes}

[1] Guatemala: Memoria del Silencio. Guatemala, GT: Comisión para el Esclarecimiento Histórico $(\mathrm{CEH})$; 1999. Available from: centrodememoriahistorica.gov.co/descargas/guatemala-memoriasilencio/guatemala-memoria-del-silencio.pdf.

[2] Guatemala: Squeezed Between Crime and Impunity. International Crisis Group; 2010. 33. Available from: https://www.crisisgroup. org/latin-america-caribbean/central-america/guatemala/guatemalasqueezed-between-crime-and-impunity.

[3] Guatemala, although a middle-income country, has the lowest taxburden in Latin America, 10.5\% of GDP in 2017 (ECLAC). Taxation is perhaps the most sensitive issue for the economic elite which has adamantly opposed fiscal reform efforts to reach the meager $12 \%$ goal set in the Peace Accords. This situation leaves the Guatemalan state perennially under-funded and is one of the main reasons why citizens procure private security services, mainly provided by former military actors, which have economic incentives to favor a weak police force and high levels of insecurity.

[4] Frühling $\mathrm{H}$. A Realistic Look at Latin American Community Policing Programmes. Policing and Society. 2012;22(1):76-88. doi:10.1080/10439463.2011.636816.

[5] Ungar M, Arias ED. Reassessing Community-oriented Policing in Latin America. Policing and Society. 2012;22(1):1-13. doi:10.1080/10439463.2011.597856.

[6] Cruz JM. Criminal Violence and Democratization in Central America: The Survival of the Violent State. Latin American Politics and Society. 2011;53(4):1-33. doi:10.1111/j.1548-2456.2011.00132.x.

[7] Macaulay F. Cycles of Police Reform in Latin America. In: Policing in Africa. Palgrave Macmillan US; 2012. pp. 165-190. doi:10.1057/9781137010582_8.

[8] CIACS stands for cuerpos ilegales y aparatos clandestinos de seguridad, roughly: illegal armed groups.

[9] Peacock S, Beltrán A. Hidden Powers in Post-conflict Guatemala: Illegal Armed Groups and the Forces behind them. Washington Office for Latin America (WOLA); 2003. Available from: https://www.wola.org/ wp-content/uploads/2003/09/HiddenPowers-Exec-Summary.pdf.

[10] Macaulay F. Cycles of Police Reform in Latin America. In: Policing in Africa. Palgrave Macmillan US; 2012. pp. 165-190. doi:10.1057/9781137010582 8.

[11] Vanderbilt University's Latin American Public Opinion Project's (LAPOP) data bases inform that the proportion of Guatemalans responding they felt unsafe went from $54.2 \%$ in 2004 to $61.14 \%$ in 2012, the year Pérez Molina took power.

[12] Trojanowicz RC, Bucqueroux B. Community Policing: A Contemporary Perspective. Anderson Publishing Company; 1990.
Totonicapán and Villa Canales who shared their knowledge and experiences with generosity. Thanks go to Ingrid Nyborg, and John-Andrew McNeish for their valuable comments and overall support, and to Adriana Gómez, Rodrigo Véliz, Benjamín Rojas and Engel Tally who provided valuable research assistance. I extend my gratitude to the two anonymous reviewers who provided constructive critical comments during the peer-review process.

Available from: https://www.worldcat.org/title/community-policing-acontemporary-perspective/oclc/4769336295\&referer=brief results.

[13] Dias-Felix A, Hilgers T. Community Oriented Policing Theory and Practice: Global Policy Diffusion or Local Appropriation? Policing and Society. 2020;pp. 1-9. doi:10.1080/10439463.2020.1776280.

[14] In Spanish, Sub-Dirección General de Prevención del Delito.

[15] Reyes F. Informe sobre Esfuerzos Preventivos en Policía Nacional Civil. Guatemala, GT: Instituto de Enseñanza para el Desarrollo Sostenible (IEPADES); 2016.

[16] Modelo Policial de Seguridad Integral Comunitaria Manual. Guatemala, GT: National Civilian Police of Guatemala (PNC); 2014. Available from: https://pnc.edu.gt/wp-content/uploads/2015/ 11/Manual-MOPSIC1.pdf.

[17] Características Generales de la Población, Resultados del Censo de Población de Guatemala 2018. Instituto Nacional de Estadísticas (INE); 2018. Available from: https://www.ine.gob.gt/ine/.

[18] Falla R. Revista Envío Digital. 2012;(368). Available from: https: //www.envio.org.ni/articulo/4614.

[19] González-Vásquez MB. Revista Escenarios Sociales. 2018;(5). Available from: http://www.ditso.cunoc.edu.gt/index.php/53/autoridadescomunales-48-cantones-de-totonicapan/.

[20] de Maillard J, Roché S. Studying Policing Comparatively: Obstacles, Preliminary Results and Promises. Policing and Society. 2016;28(4):385-397. doi:10.1080/10439463.2016.1240172.

[21] The PNC's funding is provided by the national government. It does not depend upon municipal structures or resources to function.

[22] Sieder R. Contested Sovereignties: Indigenous Law, Violence and State Effects in Postwar Guatemala. Critique of Anthropology. 2011;31(3):161-184. doi:10.1177/0308275x11409729.

[23] In Spanish, Jefatura de Planificación Estratégica y Desarrollo Institucional.

[24] González Y. The Social Origins of Institutional Weakness and Change: Preferences, Power, and Police Reform in Latin America. World Politics. 2018;71(1):44-87. doi:10.1017/s004388711800014x.

[25] Daughter of General Efraín Ríos Montt, a military dictator during the armed conflict.

[26] Bonner MD. What democratic policing is ... and is not. Policing and Society. 2019;30(9):1044-1060. doi:10.1080/10439463.2019.1649405.

[27] Informe Anual Circunstanciado de Actividades y de la Situación de los Derechos Humanos. Guatemala, GT: Procurador de Los Derechos Humanos (PDH); 2019. Available from: https://gazeta.gt/wp-content/uploads/2020/02/IAC-PDH-2019completo-17-ENERO_final-LM-V2_G.pdf.

[28] Rojas-Ospina EJ. The Gendered Nature of Security in El Salvador: Challenges for Community-Oriented Policing. Journal of Human Security. 2020;15(2). doi:10.12924/johs2019.15020070. 